\title{
Reflecting Marxist Epistemology and the Irreligiousness of Resource Control in Gbilekaa's Bishop Bassey
}

*Olympus G. EJUE

\begin{abstract}
It is sadly recognized in Nigerian cultural history that the value on material comfort supersedes every other value irrespective of whether it has any negative connotations or not. This study, therefore, interrogates a situation whereby clergy men and women in Nigeria use religion not only as a seductive means to manipulate the masses into doing their biddings, but also as a means of survival in a harsh economy. The resultant hardship and unemployment situation in the country appear to be prompting an inevitable corollary of irreligious undertakings by dishonest clergy. The play, Bishop Bassey, typifies the problem of personal interest, subterranean underpinnings in manipulating of religion as an essential corner stone for self-aggrandizement. Simply put; it epitomizes religious deceitfulness and hypocrisies that have characterized the Nigerian religious landscape. Thus, in a metaphoric swipe of embracing Western civilization, culture and religion, the dimension to which the Nigeria populace now propagates religious doctrine has got a frightening level of deceit, slander and even character assassination in order to outwit one another in what now looks like ñ in Godôs Name PLCò venture. The warped application of irreligious doctrines as a means to an end by Bassey and Dede in Bishop Bassey tends to corroborate Karl Marxôs time-tested maxim that ñReligion is the opiate of the masses. Ò A viewpoint in which religion is seen as a free-marketsystem based on private ownership of the means of production and distribution of goods. The article holds the position that, although the dramatist, Saint Gbilekaa, berates the hardship and unemployment situation in the country, he cautions on the consequences of using religion as a manipulating tool for
\end{abstract}

* Olympus G. EJUE of the Department of Theatre Arts, Faculty of Arts,

University of Abuja, Abuja Email: olympusflex@gmail.com 
individual financial augmentation and survival. Religion, in this instance, becomes an instrument of oppression and economic gains in the hands of capitalist clergy. Consequently, Bassey and Dede are in turn portrayed as victims of a conscious breach in the social contract between the masses and their leaders.

Keywords: Marxist, Irreligious, Manipulating, Aesthetics, Theatre, Saint Gbilekaa

\section{Introduction}

Marxism is a method of societal analysis that focuses on class relations and societal conflicts, following the dialectical materialism of Karl Marx based on the belief that ideas arise only as a result of material or economic conditions (favourable or otherwise) to further necessitate a conscious desire to acquire as much material wealth as possible thereby resulting in class struggle. The obvious calculation is that the rich has all it takes (means of production) to acquire more and the poor has nothing but brains and brawns to scratch at the encrustations of societal topsy-turviness.

Advancing the validity of Marx belief, Saint Gbilekaa uses his play - Bishop Bassey not only to portray religion as a stupefying phenomenon on a bored populace, but also as a manipulating tool for individual financial augmentation. In other words, religion is portrayed as a phenomenon that is motivated by profitable gains and control of the resources that can accrue from it. The play uses Marxism as a tool that is strongly opposed to religion. Religion from the Marxist point of view is perceived to be a phenomenon that has an inductive effect of what brings relief or weariness on the oppressed people of any society. Hence, it is seen as a contrivance meant to fool or hoodwink the masses. In fact, in so many societies the world over, this opium of the people has been used by the ruling class over the years to magnify and give false hope to an imagined future utopian age of joy, peace and abundant prosperity for the masses. This is done in respect of the fact that the working class perceives it (religion) as a form of protestation against their economic conditions. This becomes true 
of Gbilekaaôs Bishop Bassey, wherein two characters in search of livelihood decide against all things to establish a church in order to take undue advantage of manôs long rumoured quest for spiritual uplifting and economic prosperity.

Thus ñleaning on notable Marxist aestheticians, Gbilekaa identifies two main strands of radical theatre in Nigeria, namely; that practiced in conventional Western theatre and directed at a literate audience on one hand, and a community or popular theatre, on the otherò (Darah 67). This is an indication that Gbilekaa finds relevance in challenging classical conventions which, to a large extent, appear not to be amenable to innovation and changes that could characterize postmodernist theatre practice in Nigeria. Indeed, Gbilekaaôs theatrical platform assumes a slight departure from that of the first generation dramatists like Soyinka, J. P. Clark, Ola Rotimi, etc., whose predominant ideology of conformism and animist metaphysics preoccupies their style of writing. It is clear today that contemporary theatres the world over are proving to have concrete alliances between the playwrightsô and their audiences. In other words, the playwrights formulate the dialogue of our epoch and also find a way of giving expressions to its inspirations. They (playwrights) are sometimes described as ñseers, prophets, visionary and even fortune tellers. Consequently, the so-called primitive society sees him or her as a medium $\ddot{i}$ the ǵo-between-contactô between the people and the unseen forcesò (Kofoworola 77). This stand is obviously not unconnected with the fact that:

Life has become precarious, death and violence stalk our every footstep. Hunger and squalor, disease and agony are everywhere in the street. It has become a veritable struggle to stay alive, and remain human. (Osofisan 4)

Therefore, the idea of a church as a golden route that ultimately leads to a life of wealth, affluence and economic fulfillment struck Bassey, the theatre artist and Dede, the scientist only as a direct panacea to wretchedness, hunger and abject squalor and poverty. This is a clear indication that material 
conditions give fillip to ideas.

\section{Marxist Aesthetics and the Nigerian Theatre}

In the world today, all culture, all literature and arts belong to definite classes and are geared to definite political lines. There is, in fact, no such thing as art for art sakeé (Tung 25). The aesthetic idea of Marx on literature and art as investigated by Gbilekaa is handy here to further explain clearly the relationship between art and ideology and the class character of art in which far-reaching transformation of human reality is based on a dialectical explanation of times gone by. To the Marxists, commitment in art is dialectical. It entails going to the roots of the problem by unearthing the class formations, the on-going class war that perpetuates injustice, misery and poverty. In other words, the áommittedô writer preaches the changeability of old, archaic institutions and demystifies capitalist myth by attacking the status quo, educates the people; create hope in them in such a way that they become confident of making changes. The view of literature as a conscientization mediumé (Gbilekaa 51-52).

History has it that even the classical Greek playwrightôs like Aeschylus, Sophocles, Aristophanes and Euripedes to an appreciable extent did echo in their plays, the cosmic realities. Nwosu suggests quite correctly that ñsame practice applies to medieval playwrights who projected the medieval religiosity in their morality and mystery plays. The renaissance writers even up to the modern and postmodern playwrights also reflected social realities in their worksò (7). The experience of this disconnect, due to the deadly blow dealt Africa by the imperialists in terms of social relations and community values, there have been conscious efforts by Nigerian dramatists over the years to articulate and interpret the realities and aspirations of our tempestuous society. Arts, therefore, become phenomenal to the values and socio/cultural underpinnings of a society in a manner that it cannot be conceived in an abstract mechanistic conception.

The drama import of Gbilekaa at this instance, aims at not only to awaken the consciousness of his audience who in turn must see themselves as agents of change, but display a displeasure of the idealist vision based on animist metaphysics of his predecessors. 
The basic thrust via Marxist aesthetics according to Adeniyi in a keynote address to Theatre and Politics in Nigeria is that which stands to promote and ñreinforce structures that reduce our capacity to achieve the goals of self-determination and actualizationò (iv). This cultural renaissance is noticeable in the creative craft of Wole Soyinka, J.P. Clark, Rotimi, Bode Sowande, Femi Osofisan, Kola Omotoso, Rasaki Ojo Bakare, Alex Asigbo, Tunde Fatunde, Sam Ukala, Segun Oyekunle, Bode Osanyin, Tracie Utoh-Ezeajugh, Olu Obafemi, Tess Onwueme, Effiong Johnson, Ahmed Yerima, not forgetting Gbilekaa and a host of others. It is against this backdrop that these dramatists, particularly the latter ones recapitulated their dramas in a form of revolt and protest against the imperialistsô literary ideology and legacy to Nigerian theatre. Obafemi argues that:

In a direct way of re-interpreting history, away from the tragic, reformist and idealist dimension, these dramatistsé take on both urgent and topical matters that plague society and open up discussion with their audiences as to how best to come into new self and collective liberator awareness. (7)

It is an experience of the dominant preoccupation of the theatre enforcing total radicalization of mass consciousness. In fact, this posture jettisons the philosophy that presents life as static and humanity a mere pawn in the hands of the gods. Gbilekaa reaffirms this emergent revolutionary theatre and testimonies. He says that: in the theatrical idiom, post-independent drama expressed the new national consciousness. Rejecting his erstwhile Eurocentric aesthetics socialization and ideological bent, the Nigerian playwright together with the novelist looked back into their archival past with the aim of unearthing the rich culture, philosophy, poetry, dignity, in fact values that the colonialists had wantonly destroyed (3).

This preposition is further strengthened in a platform where he (Gbilekaa) condemns the logic of converting from a colonial to post-colonial via the dialectics of globalization and the Nigerian socio/political existence. Gbilekaa encourages Nigerian writers to 
use their social experience in responding and engaging the consciousness of the Nigerian masses through their creative endevours. With the numerous examples of creative works from Soyinka, CypriN Ekwensi, Chinua Achebe, Ben Okri, Niyi Osundare, Chimamanda Adachie, Herbert Ogunde, Elechi Amadi, he believes that ñone of the major ways which the image of a new Nigeria can be constructed and reinforced is through her literature. Nigerian literature has no doubt carved a global niche for itselfò (Gbilekaa 315).

It is important to observe that Nigerian playwrights at this time had become knowledgeable of the cosmic laws that govern their society and indeed all the necessary artistic symbols that could add value and relevance to their works. Just like Gbilekaaôs Bishop Bassey, Soyinkaô Jero in The Trials of Brother Jero epitomizes religious deceitfulness and hypocrisies that have characterized the Nigerian religious landscape. Yerimaôs The Bishop and the Soul and Thank You Lord with the themes of jealousies, temptations and rivalries; Emmanuel Okomôs God on Trial and the Boko-Haram saga and betrayals all collective memories of imperfections of a creative repertoire from which these playwrights draw. It is this commitment that injected the Marxist perspective at the expense of the status quo in Nigerian drama as an alternative to dethrone the epoch of tyrants and megalomaniacs in the Nigerian polity. It was a period that recorded the emergence of a theatrical socialist revolution of a theatre of commitment and ideology with Osofisanô Once Upon Four Robbers, Morountodun and so on; Sowandeôs The Night Before, Farewell to Babylon which he termed ópiritual nationalismôwhich all began to re-examine their society from a dialectical materialist viewpoint with a view to capturing the yearnings and aspirations of the common man. It is perhaps against this backdrop that Obafemi avows that:

Their work deals, urgently, with contemporary social problems in Nigeria with the aim of raising mass awareness of a positive revolutionary alternative to the present decadence. They deal with subjects 
as topical as the phenomenon of armed robbery, studentsô rampage, class struggle, corruption, fierce anti-capitalism and feminist concerns. (168)

The Marxist ideology and literature employed by these playwrights is that of a theatrical medium that is not just sheer propaganda art, but that which commands mutual influence and sees art as an instrument of social change. Albeit, Rotimiôs ideological vision is most times viewed from an animist metaphysical perspective. However, his later plays, for example, Hopes of the Living Dead is ñnequivocally a theatre of human struggle and human liberation through collectivism, which all radical, dialectical theatre subscribe toò(Obafemi 5). It is, therefore, particularly important to note that, at this point, Rotimiôs creative activity is adjudged as characterized by áim-settingôand pure radicalization of mass consciousness. This fundamentally new ideological and radical bent situates Rotimi as having the same artistic thought with Osofisan, Omotoso, Obafemi, Oyekunle, Onwueme and Fatunde. However, it is worthy to mention that Sowande and Osofisan are fitting types in the Nigerian dramatic plateau whose social dimensions of social duty articulates societal matters with Marxist underpinnings. This assertion is well elaborated by Uche-Chinemere who considers them:

As dramatists who wrote when the Marxist/Socialist reductionist philosophy was very prominent, most of their plays chant and celebrate the ideologues and slogans associated with the Marxist school. (12)

These iconoclasts triggered a lot of interest and followership as later dramatists and theatre scholars keyed into theories and thematic metaphors that articulated their artistic efforts as momentous examples of revolutionary theatre. To a large extent, efforts of these playwrights r̃become a matter of exigency, therefore, to see the committed theatre as a strong dialectic link with politics, ideology and economics. The result of this awareness 
brings us to reality and rekindles our consciousness in community developmentò (Ejue 181). It is in the same vein that Azeez opines that ñthe modern artist or activist of the theatre must go beyond Brecht, beyond Piscator, beyond Sartre and Beckettò (45). This is because the Nigerian artist needs to appraise his or her strategies with a view to remaining relevant to society.

\section{Marxist Perspectives in Gbilekaa's Bishop Bassey}

Bishop Bassey is a documentation of Gbilekaaôs Marxist viewpoints in which religion is seen as a free-market-system based on private ownership of the means of production and distribution of goods. It is a reflection in which men and women sometimes arbitrary seek togetherness through a complex mechanism with the view to elect for themselves, leaders to whom they would give the power to control the sources of production, distribution and exchange in exchange for protection and provision. For Gbilekaa, as a playwright, religion has become an instrument of oppression and economic gains in the hands of the capitalist. This to a certain extent explains the ideological content of the play that is directly associated with social consciousness and the search for the meaning of human life. In the play, two major characters ï Bassey and Dede are victims of a conscious breach in the social contract between the masses and their leaders. Consequently, it reflects the life of man or woman in a state of nature to which the trappings of poverty and hardship are associated. The theme of religion is used to preach ógodliness with contentmentô which sermonizes the popular gospel song:

All things bright and beautiful

All creatures, great and small

All things wise and wonderful

The lord God made them all

The rich man in his mansion

The poor man at his gate

The lord God made them so

(Emphasis mine) 
With this kind of sermonic pretence circulating Christendom, Christianity among a host of other religions in the world makes itself ready tool in the hands of capitalist oppressors who would rather have the poor remain poor or grow poorer and the rich remain rich or grow richer. Bassey and Dede opted to establish a church, not a school or any other genuine business venture due to a combination of quick thinking and guile. In fact, this decision was by no means an accident, but precipitated by the level of severe lack of food and poverty ravaging the land. Besides, the fact that people could walk naturally into any building that looks like Godôs business is being discussed in the play. Like con artistes, Bassey and Dede knew that establishing a church is the only way they could defraud the poor and the rich alike and not be arrested for it.

Thus, the play, Bishop Bassey, is a satire that lampoons the deceptive irreligiousness that has typified contemporary places of worship in Nigeria. The play raises major disturbing issues about the faith of the average man or woman in society. Bassey and Dede are plagued by economic and political injustice in the Nigerian society; hence, they decided to be creative in their own uncanny way by impersonating as sincere men of God in order to create wealth for themselves. But no sooner than they started, crises of ownership and resource control amongst them erupted. And this brawl eventually leads to the tragic end of Bishop Bassey. Invariably, religion is portrayed as a concept that strives on makebelief. Marx had even described it as the opium of the masses. Asigbo and Ejue believe it is ñ situation whereby leaders use religion as a seductive means to manipulate the masses into doing their biddingsò (68). This is further confirmed by Helen, a member of Bishop Basseyô church as she testifies that:

Two Sundays back, Bishop Bassey talked about the importance of sowing a seed if we needed special favours from God, and I did. Just a week after, a contract I have been pursuing for months without any headway was awarded to me. I sourced money without any problem and I was paid a week 
after delivery. I hereby bring this token to the lord. Praise the lord. (Gbilekaa 16)

This testimony is either false or ill-dated. If the Bishopôs sermon on ñthe importance of sowing seedò was preached two Sundays ago, and a week later, she was awarded a contract, then something is fundamentally wrong. Assuming it took Helen just one week to source for funds to fulfill and deliver on the contract, it then means two Sundays would have already elapsed. Since it took another whole week for her to get paid, then it automatically means that she would only get her chance to testify on the fourth Sunday. By this calculation, therefore, it becomes clear that Helen is being paid to give false testimony just to keep the hopes of the other members high and encourage them to sow bigger seeds in order to get bigger favours from God. Other testifiers toeing similar path also confirmed having sown a seed just before their so-called miracle took place. Barbaraôs prayer for the offering session of the church service proves an unholy and unscriptural love for money. Hear her:

Heavenly and thundering one, who sits atop mountains and resides in the abyss of the oceans, omnipresent and beneficent one who knows all our minds, you who sees the contents of our pockets and banks. We do not only evoke your presence here but also ask you to bless those who have given generously for your love cheerful givers.

For those who have offered only twenty or fifty naira, lord, please have mercy on them, change their stingy nature so they would learn to return to the lord in large measure what the lord has generously given them. Amen. (Gbilekaa 13-14) (Emphasis mine)

This is a lampooning of the modern day new generation churches where craving for material wealth has taken the place of God in the hearts of men and women. For Barbara, it is a sin for people to give twenty or fifty naira as offering in church; a sin 
requiring Godôs forgiveness and deliverance. Bishop Bassey, who only a few months back was dying of hunger in a shared one room apartment, is already asking for five persons who would donate ten million naira each to support the completion of the churchôs building. Like a people hypnotized, members stood up one after the other to make donations. This irrational demand for money and other material things cannot be justified by any stretch of moral indices. In contemporary Nigerian society, this is a common phenomenon amongst the so-called preachers of the word of God, with two faced-insincere dealings with people, especially by being outwardly friendly, but secretly disloyal even to God Himself.

On $14^{\text {th }}$ of August, 2013, Peniel Plus, a Nigerian blogger published an article on www.Ynaija.com in which Bishop Adeboye, the senior pastor and founder of the Redeemed Christian Church of God (RCCG) was quoted as saying:

We need one billion naira from ten people, if you are one of them, please see my personal secretary after we finish today. We also need one hundred million naira each from those who can afford it. If you are in that category, please see my personal secretary as well.

With this kind of pronouncement coming straight from such a highly placed and respectable man of God, it becomes clear that it is only by being able to donate a certain amount of money that one can qualify to see Bishop Adeboyeôs personal secretary. If it cost this much to see Bishop Adeboyeôs personal secretary, how much more Adeboye, then of course God Himself. There is also the argument that schools built with church membersôdonations are the most expensive in Nigeria, especially tertiary institutions. Such institutions are priced so high that only a handful of such church members can actually afford to send their children there. These events only confirm the Marxist scepticism that religion is a capitalist device used to rob the poor and pay the rich.

Furthermore, a closer look at the script supports the Marxist conception of the struggle for the control of economic power. Bishop Bassey decides to take for wife Barbara of her 
melodious voice. He also converts the church business jointly owned by him and Dede to a private and family business. As if this is not enough, Bassey tries to frustrate, deny, emasculate and relegate Dede from being the church treasurer to nobody or a mere ónch warmerô in the church. This decision does not go down well with Dede who resultantly demands a payoff. In his greed and capricious self-righteousness, Bishop Bassey feigns ignorance of any business deal with Dede and instead begins to preach the gospel of salvation to him. It became a tussle and wit contest of áither, oré ôbetween Bishop Bassey and Dede. Thus, almost like the willowy body of joy which Rotimi describes in The gods Are Not to Blame as having ña slender body that breaks too sooné There is trouble now in the land, joy has broken and scattered; peace too is no moreò. (8). Dede contracts hired killers to assassinate Bishop Bassey in his house. It becomes clear that the struggle over who controls the resources of the church became the bane between Bishop Bassey and Dede and eventually leads to the tragic death of Bishop Bassey.

\section{Conclusion}

The proliferation of churches in contemporary society is becoming worrisome. This is particularly so because certain disclosures are revealing deceitfulness, undue assertiveness to control monetary or other resources of the church, and above all, the general ungodly tendencies of the owners/founders of these churches. Moreover, this unparalleled greed and urge to control power and finances within the church domain at all costs is what leads to divisive unpleasant split among members. Gbilekaaôs play, therefore, is an attack on arrogance, megalomania and deceit. The play identifies with the dialectical materialism of Karl Marx which hinges on the belief that a manôs or a womanôs financial status controls and determines his or her reasoning and his or her material condition defines his or her ideas. In as much as he did not lay much blame on his major characters, it is still clear that he abhors what they became. Rather than condemn the two graduates, he lambasts the Nigerian society for being responsible for what they Bassey and 
Dede) became. Against this backdrop, Gbilekaa advises the Nigerian society to reflect on the broad spectrum of complexities and challenges of the universe and how people can consequently understand and come to terms with the multipart of their environment. He philosophizes this in the words of Bassey that:

Humanity in its entirety abounds in rich resources. The lazy, prone to idleness sit down grumbling, the creative, without boundaries regale in their creativity. I sought life, I found it, like nectar, I savoured it and the swan I will bid it farewell with a song. The lord giveth, the lord taketh, it was good while it lasted. Blessed be the name of the lord.(44-45)

Invariably, he encourages the poor to try and be creative rather than sit down and resign to fate. He advocates some sort of revolution in which creativity instead of violence would be the instrument of the poor in redefining and determining their own destinies. Essentially, Bishop Bassey establishes an ideological consciousness in the comity of radical scholarship in the Nigerian theatre through a critical Marxist framework and stagecraft. The play provides pedagogical strategy and theoretical moorings to animate a theatrical vision which exudes a certain tendentiousness of revealing art as the handmaid of socio-political ideological trappings that presents a vision of the world in transformation. 


\section{Works Cited}

Adeniyi, Tola. ñSONTA Keynote Addressò Theatre and Politics in Nigeria. (1993): iv-x. Print.

Asigbo, Alex C. and Ejue, Olympus G. ñEvolving a Universal Culture for Peace, Good Governance and Sustainable Development in Nigeria.ò The Humanities and Good Governance. Ed. A.B.C. Chiegbokaetal. Awka: Rex Charles and Patrick Ltd., 2012: 65-69. Print.

Azeez, Tunji. r̃Playwriting, Creation and Production: Charting a New Course for Social Relevance in the Next Millennium.ò Nigerian Theatre Journal 5.2 (1999):45-50.Print.

Darah, Godini G. Radicals, Literature and Nigeria: Just Before 2014. The Kole Omotoso@70 Lecture Delivered at the Cultural Centre, Akure, Ondo State, April, $20^{\text {th }}, 2013$.

Ejue, Olympus G. ñTheatre of Commitment in Nigeria: A Socio/cultural Paradigmò. The Abuja Communicator: A Journal of Culture and Media Arts 1.2 (2002): 178-188. Print.

Gbilekaa, Saint. ñTheatre and Political Change in Nigeria since Independence.ò Theatre and Politics in Nigeria (1993):111. Print.

. ñNigerian Literature and Social Experience: The Zaki Biam Episode.ò Culture, Identity and Leadership in Nigeria. Ed. Emmanuel S. Dandaura and AbdulRasheed A. Adeoye. Ibadan: Kraft Books Limited, 2010. Print.

. Radical Theatre in Nigeria. Ibadan: Caltop Publications (Nigeria) Limited, 1997. Print.

. Bishop Bassey. Markudi: Sevhage Publishers, 2014

Kofoworola, Zikky O. ñFrom Mansions of Thoughts to Realities: A Discourse on Performance Theories and the National Question.ò Nigerian Theatre Journal (2004): 75-87.Print.

Nwosu, Canice C. Postmodernism and Paradigm Shift in Theory and Practice of Theatre.

Onitsha: Eagleman Books, 2014. Print. 
Obafemi, Olu. Contemporary Nigerian Theatre: Cultural Heritage and Social Vision. Lagos: Centre For Black and African Arts and Civilization (CBAAC), 1996. Print. .ñThe Role of the Theatre in Sustaining Democracy in Nigeria.ò The Performer: Ilorin Journal of The Performing Arts 4(2002):1-10. Print.

Osofisan, Femi. Midnight Hotel. Ibadan: Sam Bookman, 1988.Print.

Peniel, Plus. Opinion: No! Pastor Adeboye, Your approach is wrong. Web. 12 Mar. 2013 <www,ynaija.com>.

Rotimi, Ola. The gods Are Not to Blame. London: Oxford University Press, 1998. Print.

Tung, Rosemarie. Feminist Thought: A Comprehensive Introduction. Colorado: Westview Press, 1989. Print.

Uche-Chinemere, Nwabueze. ñPerceptual Complementarity and Alternative Readings: Deconstructing the Heroes of Radical Nigerian Drama.ò West African Theatre and Performing Arts Journal (WATPAJO) 1.1 (2001):12-27. Print. 